\title{
JAWNOŚĆ POSTĘPOWANIA KARNEGO A PRYWATNOŚĆ JEGO UCZESTNIKÓW W SPRAWACH O PRZESTĘPSTWA NA TLE SEKSUALNYM. ASPEKT PRAWNOPORÓWNAWCZY
}

\begin{abstract}
Streszczenie. Artykuł dotyczy problemu kolizji prawa do prywatności z zasadą jawności zewnętrznej oraz z niektórymi innymi zasadami procesu karnego w sprawach, w których przedmiotem postępowania jest przestępstwo na tle seksualnym. Autorka, przedstawiając uregulowania polskie na tle regulacji hiszpańskich oraz odwołując się do kampanii społecznych i rozwiązań funkcjonujących w innych krajach europejskich, stara się wykazać, jak ważna jest ochrona godności i prawa do intymności ofiary w kontekście zapobiegania wtórnej wiktymizacji oraz przedstawić mechanizmy zapewniające taką ochronę. Autorka analizuje również kwestię ochrony prawa do prywatności oskarżonego. Jako że zasada jawności zewnętrznej jest ściśle związana z dostępem mediów do procesu, opracowanie poświęcone jest także problemowi sprawozdawczości radiowo-telewizyjnej w kontekście rozwoju nowych mediów, ze szczególnym uwzględnieniem spraw, których uczestnikami są osoby publiczne.
\end{abstract}

Słowa kluczowe: zasady, proces karny, prawo hiszpańskie, wtórna wiktymizacja, prawo do prywatności, zasada jawności zewnętrznej.

\section{KOLIDUJĄCE WARTOŚCI}

Każdy proces karny wiąże się ze sporem, jednakże w postępowaniu ścierają się nie tylko interesy uczestników procesu - ciągłe napięcie występuje również pomiędzy całym wachlarzem zasad procesowych i chronionych prawnie wartości. Proces, ze swej natury nastawiony na wydanie orzeczenia, w każdym fragmencie wiąże się z podejmowaniem szeregu jednostkowych decyzji dotyczących tego, która wartość w tym momencie powinna być w największym stopniu chroniona i która zasada będzie w danej sytuacji skonkretyzowana, a którą należy kosztem innej zasady ograniczyć. Kiedy w sprawie występują zasady konkurujące, „należy określić, do jakiego stopnia i która z nich ma pierwszeństwo, co z kolei wymusza, aby każda z zasad była urzeczywistniana w stopniu możliwie najszerszym" (Maroń 2009, 87). Część decyzji podejmuje oczywiście sam ustawodawca, jako że „granicę możliwości prawnych realizacji zasad wyznaczają przeciwstawne, konkurujące zasady i reguły prawne" (tamże), część rozstrzygnięć zaś będzie

* Uniwersytet Śląski, Wydział Prawa i Administracji, Katedra Teorii i Filozofii Prawa, paulinakonca@gmail.com. 
zapadała a casu ad casum, zważywszy na to, że „możliwości faktyczne urzeczywistnienia zasady określają zasady konieczności i odpowiedniości” (tamże). Warto przypomnieć, że w samej Konstytucji Rzeczypospolitej Polskiej z dnia 2 kwietnia 1997 r. (Dz.U. z 1997 r. Nr 78, poz. 483) mowa jest o tym, iż wszelkie zawężenia zakresu stosowania wolności i praw nie mogą naruszać trzonu tychże (art. 31 ust. 3 Konstytucji RP), a nadto spełnione muszą być przesłanki, takie jak dochowanie ustawowej formy ograniczeń czy konieczność ochrony innych wolności i praw jednostki (Garlicki 2001, 6 i n.; Łabno 2002, 699).

Jaskrawym przykładem kolidujących wartości jest jawność i prywatność. Widać to szczególnie na przykładzie spraw o przestępstwa na tle seksualnym, w których ewentualne naruszenie prawa do prywatności, w tym prawa do intymności, może być szczególnie dotkliwe. Rodzi to szereg problemów, z którymi zmierzyć się musi zarówno ustawodawca, jak i sąd.

O jak szerokim stopniu urzeczywistnienia wymienionych wartości możemy mówić w sprawach o przestępstwa na tle seksualnym? Czy zasada jawności zewnętrznej w takich postępowaniach ma w ogóle rację bytu? Do jakiego stopnia intymność uczestników powinna być chroniona w postępowaniu? Czy prowadzenie rozprawy przy drzwiach zamkniętych rozwiązuje wszystkie problemy, z którymi wiąże się potrzeba respektowania prawa do prywatności w procesie karnym? Jakie ograniczenia innych zasad procesowych są pożądane i możliwe w celu realizacji prawa do prywatności uczestników postępowania?

\section{ZASADA JAWNOŚCI ZEWNECTRZNEJ PROCESU KARNEGO}

Zgodnie z zasadą jawności zewnętrznej sprawa powinna być rozpoznawana publicznie - na rozprawie, do której dostęp ma każdy zainteresowany. Już Jeremy Bentham pisał, że ,jawność jest duszą sprawiedliwości”, ponieważ „to poprzez jawność sprawiedliwość staje się matką bezpieczeństwa” (za Postema 2013, 1). Zasada jawności chroni strony przed niejawnym działaniem wymiaru sprawiedliwości, arbitralnymi rozstrzygnięciami sądu oraz służy umocnieniu niezawisłości sędziego. Publiczne rozpatrzenie sprawy ma umożliwić zewnętrzną kontrolę postępowania sądowego, sprawowaną przez szeroko rozumianą publiczność, w tym poprzez media.

Zasada jawności zewnętrznej jako jedna z kluczowych zasad procedury karnej, ukształtowanej w państwie demokratycznym, została wyrażona w podstawowych aktach prawa międzynarodowego'. Dyrektywa jawności postępowania została również ujęta w art. 45 Konstytucji RP, w którym powiązano zasadę

${ }^{1}$ Art. 10 Powszechnej Deklaracji Praw Człowieka z dnia 10 grudnia 1948 r.; art. 14 ust. 1 Międzynarodowego Paktu Praw Obywatelskich i Politycznych; art. 47 Karty praw podstawowych Unii Europejskiej; art. 6 ust. 1 Europejskiej Konwencji o Ochronie Praw Człowieka i Podstawowych Wolności. 
jawności z prawem do sądu, czym ustrojodawca nawiązuje do unormowań traktatowych (np. do art. 14 ust. 1 Międzynarodowego Paktu Praw Obywatelskich i Politycznych z dnia 19 grudnia 1966 r., Dz.U. z 1977 r. Nr 38, poz. 167) i orzecznictwa Trybunału Konstytucyjnego (wyr. TK z dnia 9 czerwca 1998 r., K. 28/97, OTK 1998/4/50; wyr. TK z dnia 8 grudnia 1998 r., K. 41/97, OTK 1998/7/117; wyr. TK z dnia 16 marca 1999 r., SK 19/98, OTK 1999/3/36). Wskazać należy, że zasada publiczności jest gwarantowana na poziomie ustawy zasadniczej nie tylko w Polsce. Ponieważ w dalszej części tekstu znajdują się odwołania do regulacji hiszpańskich, jako przykład przywołać należy Konstytucję Hiszpanii (art. 24 ust. 2 oraz art. 120 Constitución Española z dnia 29 grudnia 1978 r., BOE-A-1978-31229)².

\section{PRAWO DO PRYWATNOŚCI I JEGO OGRANICZENIA}

W piśmiennictwie prawo do prywatności definiowane jest m.in. jako prawo do odosobnienia, co oznacza, że człowiek może tak kształtować prywatną sferę życia, aby była ona niedostępna dla innych i wolna od ingerencji (Braciak 2004, 36). W orzecznictwie podkreśla się, iż jednostka, jako podmiot obdarzony autonomią woli, ma prawo samodzielnie wyznaczać obszar swojej prywatności, w szczególności wytyczać granice dostępności swojego życia osobistego dla innych (wyr. SA w Warszawie z dnia 12 listopada 2013 r., I ACa 906/13, LEX nr 1409385). Także w hiszpańskim orzecznictwie zwraca się uwagę, iż prawo do prywatności łączy się z obszarem, który człowiek stara się ukryć przed wzrokiem osób postronnych (Sentencia del Tribunal Constitucional 151/1997 z dnia 29 sierpnia 1997 r., BOE nr 260 z dnia 30 października 1997 r.). Wskazać można różne aspekty prawa do prywatności - autonomię fizyczną, terytorialną, komunikacyjną oraz informacyjną (Braciak 2004, 41). Proces karny wiąże się z niebezpieczeństwem naruszenia wszystkich tych sfer, jednak w kontekście jawności rozprawy najistotniejsze jest naruszenie autonomii informacyjnej. Prawo do prywatności podlega również ochronie w porządku międzynarodowym, np. art. 8 Konwencji o Ochronie Praw Człowieka i Podstawowych Wolności z dnia 4 listopada 1950 r. ze zm. (Dz.U. z 1993 r. Nr 61, poz. 284) czy art. 17 MPPOiP, oraz jest chronione na poziomie konstytucyjnym (art. 47 Konstytucji RP, art. 18 ust. 1 Konstytucji Hiszpanii).

Prywatność nie ma charakteru absolutnego. Wyróżnia się wertykalne ograniczenia prawa do prywatności, czyli te służące niezbędnej ochronie interesów społecznych, oraz ograniczenia horyzontalne, które służą ochronie interesów indywidualnych (Braciak 2004, 53). Jak wskazuje się w judykaturze, ochrona prywatności nie ma charakteru absolutnego między innymi ze względu na potrzeby życia w zbiorowości. „Nie jest możliwe wypracowanie w tej kwestii jednoznacznych

${ }^{2}$ W Konstytucji Hiszpanii odróżniono gwarancję jawności jako taką (art. 120) od prawa do jawnego procesu będącego składową prawa do sądu (art. 24 ust. 2). 
i wyczerpujących kryteriów, które mogłyby odnosić się do wszystkich sytuacji. Ocena $w$ tych sprawach będzie z natury rzeczy zrelatywizowana do istniejących, konkretnych okoliczności i uwarunkowań" (wyr. SA w Katowicach z dnia 20 września 2012 r., V ACa 378/12, LEX nr 1220491). W orzecznictwie podkreślono, że sfera życia prywatnego (w tym również życia intymnego) w zestawieniu $\mathrm{z}$ innymi konkurencyjnymi wartościami

wykazuje taką doniosłość, że jej naruszenie zasługuje z reguły na ujemną ocenę, a tylko wyjątkowo mogą wystąpić okoliczności uchylające tę ocenę, przy czym do okoliczności tych należy w szczególności ujawnienie wobec sądu i innych podmiotów uczestniczących w postępowaniu sądowym faktów ze sfery życia intymnego, jeśli ujawnienie takie pozostaje w związku z dochodzeniem lub obroną własnych praw (wyr. SA w Krakowie z dnia 11 kwietnia 2001 r., I ACa 244/01, TPP 2002/3/125).

\section{REGLAMENTACJA JAWNOŚCI ZEWNETRZNEJ W PROCESIE KARNYM}

Także zasada jawności postępowania nie ma charakteru absolutnego (wyr. TK z dnia 2 października 2006 r., SK 34/06). Choć jawność postępowania powinna być traktowana jako warunek rzetelnego procesu, nie jest ona dobrem najwyższym i często musi ustąpić ochronie innych wartości (Zgryzek 2014, 798). Wyjątki od tej zasady są wyszczególnione w prawie międzynarodowym, a także w ustawie zasadniczej i zwykłej. O ile przepis art. 45 ust. 1 Konstytucji RP gwarantuje prawo do jawnego rozpoznania sprawy, o tyle przepis ust. 2 określa dopuszczalne granice wyłączenia jawności. Jak wskazuje się w orzecznictwie, podstawy do wyłączenia jawności są ściśle określone w art. 45 ust. 2 Konstytucji RP i w żadnej z ustaw zwykłych ten katalog podstaw nie może być poszerzony (post. SA w Warszawie z dnia 19 grudnia 2013 r., II AKz 856/13, LEX nr 1403834). Wśród podstaw tych wymienia się m.in. ochronę życia prywatnego stron lub inny ważny interes prywatny. Przepis ten może rodzić pewne wątpliwości co do uznania pokrzywdzonego nieposiadającego statusu strony za osobę, ze względu na której prywatność możliwe jest ograniczenie jawności procesu. W doktrynie wskazuje się jednak, że ustrojodawca prawdopodobnie miał na myśli strony w sensie przeciwników procesowych, czyli bezpośrednio zainteresowanych treścią rozstrzygnięcia uczestników postępowania sądowego (Koper 2010, 224).

Również w ustawie z dnia 6 czerwca 1997 r. - Kodeks postępowania karnego (tekst jedn. Dz.U. z 2016 r., poz. 1749 ze zm.) znalazły się wyjątki od zasady jawności (wyrażonej w art. 355 k.p.k.). Ustawodawca uregulował przypadki niejawności ex lege, a także wyłączenia jawności z urzędu lub na żądanie strony. W orzecznictwie wskazuje się, że wyłączenie jawności postępowania powinno w każdej sprawie być ograniczone do niezbędnego minimum. Obowiązek obrony innych dóbr realizowany przez sąd musi być pogodzony z prawem strony do jawnego rozpoznania jej sprawy w takim zakresie, w jakim jest to możliwe (post. SA 
w Warszawie z dnia 19 grudnia 2013 r., II AKz 856/13, LEX nr 1403834). Warto też podkreślić, że jeśli prokurator sprzeciwi się wyłączeniu jawności, rozprawa odbywa się jawnie (art. 360 k.p.k.).

Jedną z przesłanek wyłączenia jawności jest właśnie niebezpieczeństwo naruszenia ważnego interesu prywatnego. Wyłączenie jawności będzie szczególnie pożądane, gdyby miały zostać ujawnione tzw. dane wrażliwe. W orzecznictwie wskazuje się, iż ważny interes prywatny, który uzasadniałby wyłączenie jawności, dotyczy sytuacji odnoszących się do sfery prywatnej uczestnika procesu, w tym oskarżonego, których publiczne ujawnienie mogłoby realnie, a na dodatek zbędnie, wyrządzić krzywdę temu uczestnikowi albo innym osobom, pod warunkiem, że nie dotyczy to okoliczności objętych opisem czynu lub wskazujących na motywację oskarżonego. Istotne jest przy tym zawsze rozważenie, czy publiczne ujawnienie pewnych faktów, także w mediach, nie jest jednak niezbędne do zapewnienia opinii publicznej rzetelnej informacji o danej sprawie i dla zrozumienia przesłanek, na jakich oparto wydane orzeczenie (wyr. SA w Gdańsku z dnia 8 kwietnia 2015 r., II AKa 79/15, LEX nr 1927698).

Istnieje szereg przesłanek, by w sprawach dotyczących przestępstw na tle seksualnym sądy wyłączały jawność rozprawy, warto bowiem dodać, że w sprawach o przestępstwa na tle seksualnym wyłączenie będzie następowało nie tylko ze względu na prywatność. Sąd może wyłączyć jawność rozprawy w całości albo w części między innymi wtedy, kiedy jawność mogłaby obrażać dobre obyczaje, przy czym w doktrynie jako podstawę takiego wyłączenia podaje się właśnie rozpoznawanie spraw przeciwko wolności seksualnej i obyczajności (Hofmański, Sadzik, Zgryzek 2011, 371; Jasiński 2008, 399; Koper 2010, 274).

Prowadzenie spraw o przestępstwa na tle seksualnym przy drzwiach zamkniętych jest powszechne. Zaznaczyć jednak należy, iż szczególnie w sprawach głośnych, czy to ze względu na ich drastyczność, czy też ze względu na osoby uczestników budzące szczególne zainteresowanie, pewne informacje z procesu mogą przenikać do opinii publicznej, nawet jeśli media ani publiczność nie będą miały wstępu na salę sądową.

\section{OCHRONA OFIARY PRZED WTÓRNĄ WIKTYMIZACJĄ A PROCES KARNY}

O konieczności zapewnienia środków, umożliwiających przeprowadzenie przesłuchania bez obecności publiczności w kontekście ochrony ofiar przestępstw na tle seksualnym przed wtórną wiktymizacją ${ }^{3}$, mowa jest między innymi

${ }^{3}$ Należy zaznaczyć, że wtórna wiktymizacja bywa jeszcze dotkliwiej odczuwana przez ofiarę niż wiktymizacja pierwotna, jako że większość ofiar przestępstw po przeżytej traumie nie ma odpowiednich zasobów psychicznych i fizycznych, aby się bronić, cierpi w efekcie stresu pourazowego i jest podatna na zranienie. Ponadto pośredniej rewiktymizacji ulegać mogą także osoby związane z ofiarą i będące świadkami jej krzywdy (Goetz 2012). 
w dyrektywie Parlamentu Europejskiego i Rady 2012/29/UE z dnia 25 października 2012 r. ustanawiającej normy minimalne w zakresie praw, wsparcia i ochrony ofiar przestępstw oraz zastępującej decyzję ramową Rady 2001/220/WSiSW. Dyrektywa ta miała na celu skłonienie państw członkowskich do zapewnienia dostępności środków służących ochronie ofiar i członków ich rodzin przed wtórną i ponowną wiktymizacją, zastraszaniem, odwetem oraz służących ochronie godności ofiar podczas przesłuchania lub składania zeznań.

Nie ulega wątpliwości, że wyłączenie jawności sprzyja ochronie ofiary przed wtórną wiktymizacją, jednakże nie sposób w tym miejscu nie wspomnieć, iż takie wyłączenie nie jest środkiem wystarczającym do osiągnięcia tego celu. Nawet niejawny proces stanowi bowiem ingerencję $\mathrm{w}$ sferę prywatną jednostki, $\mathrm{i}$ to ingerencję jak najbardziej uzasadnioną celami procesu. Ponadto o ile ograniczenia zasady publiczności, choć, jak podkreślono wyżej, jest ona niezwykle doniosła, nie przekreślają szansy na realizację celów procesu, o tyle zbyt duże ograniczanie niektórych innych zasad na rzecz ochrony intymności mogłoby proces sparaliżować. Zaznaczyć należy, że prawo do prywatności koliduje nie tylko z jawnością rozprawy głównej, ale także z szeregiem innych wartości i zasad - między innymi $\mathrm{z}$ dążeniem do odkrycia prawdy czy z prawem do obrony oskarżonego. W sprawach o przestępstwa na tle seksualnym, w przypadku których składanie zeznań przed sądem wiąże się z podawaniem informacji dotyczących życia intymnego, samo wyłączenie jawności nie wystarcza do rozwiązania problemu ochrony prywatności w procesie.

Zgodnie z przywołaną wyżej dyrektywą państwa członkowskie mają zapewniać, by ofiary poddano na czas indywidualnej ocenie, uwzględniającej w szczególności cechy osobowe ofiary, rodzaj lub charakter przestępstwa oraz okoliczności przestępstwa, dokonywanej zgodnie z procedurami krajowymi w celu ustalenia szczególnych potrzeb w zakresie ochrony. W ramach indywidualnej oceny uwagę zwraca się między innymi właśnie na ofiary przemocy na tle seksualnym, przemocy w bliskich związkach oraz przemocy seksualnej lub wykorzystywania seksualnego. Wszelkie udogodnienia wobec takich ofiar sprzyjają poszanowaniu prywatności, równocześnie wiążą się z pewnymi ograniczeniami jawności, a czasem i innych zasad lub praw, na przykład prawa do obrony. Ofiarom o szczególnych potrzebach w zakresie ochrony udostępnia się podczas postępowania sądowego środki zapewniające unikanie kontaktu wzrokowego między ofiarami a sprawcami, również w trakcie składania zeznań, dzięki zastosowaniu odpowiednich metod. Są to m.in. technologie komunikacyjne służące temu, by ofiara mogła zostać przesłuchana pod jej nieobecność na sali sądowej oraz środki umożliwiające przeprowadzenie przesłuchania bez obecności publiczności. Państwa zapewniają również specjalne pomieszczenia przystosowane lub nawet zaprojektowane do przesłuchiwania ofiar. W dyrektywie zwrócono uwagę także na konieczność zapewnienia warunków pozwalających uniknąć zbędnych pytań dotyczących życia prywatnego ofiary, niezwiązanych z przestępstwem. 
Analizując dyrektywę i zwracając uwagę na potrzebę ochrony prawa do prywatności w procesie karnym, nie sposób nie nawiązać do problemu pytań zadawanych ofiarom podczas postępowania. Bez wątpienia w sprawach o przestępstwa na tle seksualnym pytania te często dotyczyć muszą sfery intymnej, jednak taka obserwacja nie jest tożsama ze stwierdzeniem, że cele procesu karnego usprawiedliwiają wszelkie pytania naruszające prawo do intymności. Klasyczny przykład pytania, które nie powinno padać, a jednak zadawane jest nagminnie, to pytanie o ubranie kobiety podczas zdarzenia przemocy seksualnej. Jest ono nie tylko dowodem braku poszanowania godności i intymności ofiary, ale jest również po prostu błędne - w tym sensie, że założenie, iż istnieje zależność między strojem a napaścią seksualną, nie opiera się na faktach. Ciekawie obrazuje to między innymi słynna już praca dyplomowa fotografki Katherine Cambareri. Autorka za pośrednictwem Facebooka odnalazła studentki, które przeżyły napaść seksualną i poprosiła je o możliwość zrobienia zdjęć ubraniom, które miały na sobie, kiedy zostały zaatakowane (Frank 2016). Na wykonanych przez nią zdjęciach znajdują się m.in. flanelowe koszule, luźne T-shirty, dżinsy, długie spodnie dresowe czy wełniane swetry, a więc ubrania, które trudno uznać za prowokujące.

Inną interesującą inicjatywą, mającą na celu walkę z szukaniem usprawiedliwienia dla zachowania niezgodnego z prawem oraz będącą próbą przywrócenia podmiotowego traktowania ofiary w procesie i ochrony jej godności, jest szkocka ${ }^{4}$ kampania „This is not an invitation to rape me”. Na zdjęciach, opatrzonych hasłem „To nie jest zaproszenie do gwałtu”, pojawiły się kobiety w sytuacjach, które często uznawane są za usprawiedliwiające sprawcę. Bohaterka jednego ze zdjęć miała na sobie suknię ślubną, na innych fotografiach znalazły się kobiety ubrane w wyzywające stroje, a także pijące alkohol ${ }^{5}$.

Pytanie: „co miałaś na sobie?” to jedno z pierwszych, które przychodzi do głowy na myśl o przesłuchaniach ofiar, ale podczas interrogacji poruszane są też inne, równie wątpliwe kwestie, których podnoszenie jest ewidentnym przekroczeniem granic intymności. Jeżeli zgwałcona kobieta jest mężatką, może spodziewać się na przykład pytania, czy kiedykolwiek zdradziła męża. Należałoby zastanowić się, czy dzielenie się przez ofiarę informacjami na temat jej przeszłości seksualnej naprawdę jest istotne dla ustalenia przebiegu zdarzenia. Nawet jeśli kobieta zdradzała męża, nie oznacza to przecież, że godziła się na kontakty seksualne z każdym mężczyzną. Konieczność dzielenia się z obcymi osobami szczegółami dotyczącymi życia intymnego przypomina pewien rodzaj kary nakładanej na ofiarę. Nie ulega wątpliwości, że oskarżony musi znaleźć jakiś sposób obrony oraz że zdarza się, iż rzekome ofiary rzucają fałszywe oskarżenia. Trzeba jednak

${ }^{4}$ Według ankiet przeprowadzonych w 2008 r. w Szkocji 24\% badanych uważa, że kobieta jest częściowo odpowiedzialna za bycie zgwałconą, jeżeli w chwili ataku była pod wpływem alkoholu, a $29 \%$ badanych twierdzi, że ofiara ponosi część odpowiedzialności, jeżeli flirtowała z oprawcą (zob. Michaluk 2008).

${ }^{5}$ Zob. tamże. 
rozważyć, czy zadawanie podobnych pytań to faktycznie dobra droga dotarcia do prawdy. Przykładem kraju, w którym zgodnie z obowiązującym stanem prawnym tego typu pytania padać nie powinny, a przynajmniej muszą być traktowane z dużą dozą ostrożności, są Włochy ${ }^{6}$ (Aprile, Silvestri 2006, 82).

W Polsce istnieje wiele rozwiązań zgodnych z duchem przywołanej dyrektywy, takich jak możliwość dozowania jawności czy przesłuchiwanie ofiar w specjalnych pomieszczeniach (tzw. niebieskich pokojach), wydaje się jednak, że ochrona prywatności ofiary wciąż jest mniejsza od postulowanej w dyrektywie, zwłaszcza jeśli porównamy uregulowania polskie na przykład z regulacjami hiszpańskimi.

\section{POLSKIE REGULACJE NA TLE ROZWIĄZAŃ HISZPAŃSKICH}

Hiszpański ustawodawca bardzo skupia się na ochronie ofiary i jej prywatności, zdecydowanie dając temu wyraz w przepisach (zresztą asumpt do wprowadzenia takich regulacji stanowiła przywołana wyżej dyrektywa). W przepisie art. 681 Ley de enjuiciamiento criminal (dekret królewski z dnia 14 września 1882 r. - Kodeks postępowania karnego, BOE nr 260, z dnia 17 września 1882 r., BOE-A-1882-6036, ze zm.) ustawodawca przewidział możliwość wyłączenia jawności w celu zapewnienia odpowiedniej ochrony podstawowych praw uczestników, stwierdzając wprost, że chodzi tu w szczególności o prawo ofiary do prywatności, a także szacunek należny ofierze lub jej rodzinie. Poza tym w przepisie wyszczególniono jeszcze wiele innych środków ograniczających jawność postępowania, wskazując, że mają one służyć ochronie prywatności ofiary i jej bliskich. Sąd może zabronić rozpowszechniania albo publikowania informacji dotyczących tożsamości ofiary, faktów, które mogą ułatwić jej identyfikację w sposób bezpośredni lub pośredni albo tych okoliczności osobistych, które byłyby wzięte pod uwagę przy podejmowaniu decyzji o potrzebie ochrony. Może też zakazać uzyskiwania, rozpowszechniania czy publikowania wizerunku ofiary lub jej bliskich. Sąd podejmuje decyzję z urzędu albo na wniosek stron. Ponadto obligatoryjnie zabrania się rozpowszechniania i publikacji informacji związanych z tożsamością małoletnich ofiar lub ofiar niepełnosprawnych, wymagających szczególnej opieki, a także faktów, które mogą ułatwić ich identyfikację w sposób pośredni lub bezpośredni oraz pewnych okoliczności osobistych, które ich dotyczą. Zabronione jest też uzyskiwanie, rozpowszechnianie czy publikowanie wizerunku ofiary lub jej bliskich. Decyzję o prowadzeniu rozprawy w całości lub w części z wyłączeniem jawności sąd podejmuje z urzędu lub na wniosek stron, po ich uprzednim wysłuchaniu (art. 681 Ley de enjuiciamiento criminal).

${ }^{6}$ Jako przykład podaje się art. 472 w związku z art. 194 Codice di Procedura Penale (testo coordinato ed aggiornato del D.P.R. 22.09.1988, n. 447). 
Szczególne uregulowania dotyczące wyłączenia jawności znajdują się w przepisach normujących sytuację ofiar przemocy i przestępstw przeciwko wolności seksualnej (Ley de Ayuda y Asistencia a las Víctimas de Delitos Violentos y contra la Libertad Sexual - ustawy z dnia 11 grudnia 1995 r., 35/1995). Przepis art. 15.5 ustawy powierza prokuraturze zadanie ochrony ofiary przed wszelkimi przejawami jawności, których ofiara sobie nie życzy, a które mogłyby spowodować ujawnienie faktów dotyczących jej życia prywatnego albo uderzać w jej godność. W tym celu prokurator może, zgodnie z przepisami regulującymi procedurę karną, starać się, by sprawa była prowadzona przy drzwiach zamkniętych. Nadzwyczajnej ochronie podlegają w Hiszpanii również ofiary przemocy ze względu na płeć (violencia de género). Jak stanowi art. 63 Ley de Medidas de Protección Integral contra la Violencia de Género (ustawy z dnia 28 grudnia 2004 r., 1/2004), w działaniach i procedurach dotyczących przemocy ze względu na płeć broni się prywatności ofiary, zwłaszcza jej dane osobowe, dane jej dzieci i każdej innej osoby pozostającej pod jej opieką ${ }^{7}$. Właściwy sąd może z urzędu lub na wniosek strony zarządzić, że rozprawa będzie odbywać się przy drzwiach zamkniętych.

Tymczasem polski ustawodawca, poza wskazaniem, iż przepisy mają na celu takie ukształtowanie postępowania, aby ,zostały uwzględnione prawnie chronione interesy pokrzywdzonego przy jednoczesnym poszanowaniu jego godności" (art. 2 $\S 1$ pkt 3 k.p.k.), na temat ochrony ofiar praktycznie milczy. Wyłączenie jawności rozprawy w celu ochrony prawa do prywatności pokrzywdzonego można podciągnąc pod przesłankę naruszenia ważnego interesu prywatnego z art. $360 \S 1$ pkt 1 k.p.k. Szczególna jest także pozycja osoby, która złożyła wniosek o ściganie (art. 360 pkt 3 k.p.k.), co jest istotne przy przestępstwach wnioskowych. Warto dodać, że ustawa nie chroni wprost małoletniego pokrzywdzonego - w kodeksie mowa jest tylko o nieletnim oskarżonym oraz świadku, który nie ukończył 15 lat (art. 360 pkt 2 k.p.k.).

${ }^{7}$ Naruszenie tego przepisu stwierdził hiszpański Sąd Najwyższy w 2016 r., skazując Radiotelevisión de la Región de Murcia na zapłatę 25 tysięcy euro zadośćuczynienia ofierze przemocy ze względu na płeć za naruszenie jej prawa do prywatności oraz prawa do wizerunku poprzez pokazanie w programie informacyjnym jej twarzy oraz podanie jej imienia i lokalizacji wydarzeń. Sąd z Murcji argumentował, że dane i obrazy zostały uzyskane podczas publicznej rozprawy, celem stacji było podanie prawdziwych informacji w niewątpliwym interesie publicznym, kobieta zaś nie domagała się ograniczenia jawności i nie przychylił się do żądania ofiary, która domagała się zadośćuczynienia. Tymczasem Sąd Najwyższy stwierdził, iż fakt, że sąd nie zastosował środków ochrony, nie zwalnia mediów z oceny ewentualnej szkody, którą może wyrządzić ofierze wtórna wiktymizacja. Stacja telewizyjna musi działać profesjonalnie i ostrożnie, i nie powinna emitować nagrań, które pokazywałyby ofiarę na pierwszym planie, a technicy powinni cieniować rysy tak, by uniemożliwić rozpoznanie ofiary. Wspominanie imienia wraz z nawiązaniem do miejsca zamieszkania ofiary było niepotrzebne dla istoty treści informacji, czego dowodem są dotyczące tego samego procesu informacje przygotowane przez inne stacje. Zob. Sentencia del Tribunal Supremo 661/2016 z dnia 10 listopada 2016 r. http://www.elmundo.es/sociedad/2016/11/15/582b550de2704e 99188b45bf.html [dostęp 10.11.2017]. 


\section{PRAWO DO PRYWATNOŚCI OSKARŻONEGO}

Jeżeli chodzi o prawo do prywatności oskarżonego, w polskiej doktrynie znane są dwa poglądy dotyczące ochrony prywatności oskarżonego w procesie. Pierwszy wiąże się z podkreślaniem, iż w zakresie faktów związanych z przestępstwem, które dotyczą przebiegu zdarzenia oraz pobudek sprawcy, niemożliwe jest wyłączenie jawności rozprawy tylko z uwagi na okoliczności życia intymnego. Takie stanowisko uzasadniane jest "dokonaniem czynu godzącego w ład społeczny” (Koper 2010, 226). Opozycyjny pogląd wiąże się z niezgodą na słabszą ochronę prawa do prywatności oskarżonego. Najczęściej za bezsporną uznaje się potrzebę respektowania sfery intymnej oskarżonego, dyskusyjne zaś jest rozciąganie ochrony na inne okoliczności natury prywatnej (tamże). W doktrynie krytykuje się czasem pierwszą koncepcję, podnosząc, iż nie wolno konstruować zmniejszonej ochrony prawa do prywatności oskarżonego w oparciu o ideę swoistego odwetu (tamże, 229 i n.). Tymczasem krytyka pierwszego poglądu powinna zostać oparta raczej na innym zastrzeżeniu - nie ma wątpliwości co do tego, że sprawca dokonuje czynu godzącego w ład społeczny, natomiast istnieją wątpliwości co do faktu, że to oskarżony jest sprawcą. Trudno uzasadniać węższą ochronę prawa do prywatności oskarżonego tym, że zarzuca mu się popełnienie przestępstwa, bowiem cały czas obowiązuje jeszcze domniemanie niewinności. Jak napisał Heike Jung, zdarzyć się może, że oskarżony o spektakularne przestępstwo zostanie „dosłownie «rozebrany do naga» na oczach wypełnionego do ostatniego miejsca audytorium w ramach badania osobowości” (Jung 1988, 15). Należy przychylić się do drugiego prezentowanego poglądu i zapewnić możliwie szeroką ochronę prawa do prywatności oskarżonego. Jednakże gdy oskarżony okaże się sprawcą, niczym kontrowersyjnym nie będzie publiczne przytoczenie wszystkich dotyczących osoby sprawcy faktów związanych z przestępstwem, także tych naruszających prawo do intymności, a więc działanie według propozycji pierwszej. Bez wạtpienia jednak sposób prezentacji tych faktów nie może podsycać do samosądów ani przekreślać szansy na resocjalizację.

Zapewnienie możliwie szerokiej ochrony prawa do prywatności oskarżonego często ułatwia realizację zasady prawdy, kontradyktoryjności oraz prawa do obrony. Jak wskazano w piśmiennictwie, „właściwe urzeczywistnienie prawa do obrony może nastąpić nierzadko dopiero wtedy, gdy jawność rozprawy zostanie uchylona" (Koper 2010, 229). Oskarżony powinien mieć zagwarantowaną wolność w prowadzeniu sporu, to jest móc wybrać obronę bierną, związaną z milczeniem i postawą pasywną, stanowiącą $\mathrm{w}$ istocie odmowę dostępu do wielu informacji o charakterze osobistym, albo obronę czynną, związaną z dobrowolnym pozbawieniem pewnych wiadomości natury osobistej charakteru sekretnego. Fakt obecności na rozprawie reprezentacji społecznej mógłby komplikować podjęcie takiej decyzji (tamże, 227 i n.). 
Warto jednak zauważyć, że prowadzenie sprawy przy drzwiach zamkniętych nie zawsze będzie dla oskarżonego korzystne. Czasem nie tylko zdecyduje się on ograniczyć swoje prawo do prywatności poprzez prowadzenie czynnej obrony, ale równocześnie będzie się domagał jawnej rozprawy. Zwłaszcza gdy sprawa już w stadium ustaleń wstępnych stała się głośna, „oskarżony może być zainteresowany dużym forum, ponieważ publiczna rozprawa główna już z racji swej struktury jest nastawiona na wyjaśnienie zarzutów" (Jung 1988, 16). Należy zgodzić się z poglądem, iż orzekanie na rozprawie przy drzwiach zamkniętych w celu ochrony prywatności pozwanego powinno się odbywać za jego przyzwoleniem (Koper 2010, 227), przynajmniej w takim stopniu, w jakim pozwala na to poszanowanie intymności i godności ofiary.

\section{PROCES KARNY A MEDIA}

Zasada jawności zewnętrznej procesu karnego w sposób bezpośredni łączy się z dostępem mediów do procesu. W rozprawach sądowych rzadko uczestniczy publiczność, natomiast praktycznie wszyscy jesteśmy odbiorcami medialnych komunikatów. Marshall McLuhan wskazał, że „media są dziś główną siłą wychowującą i formującą człowieka" (za Drożdż 2012, 43). W literaturze dostrzeżono, że „dziennikarz staje się częstokroć dla wielu czytelników pierwszym nauczycielem prawa" (Parzyński 1964, 56). Tymczasem w piśmiennictwie podnosi się, iż głównym zadaniem przedsiębiorstw medialnych nie jest dziś informowanie ludzi, ale utrzymanie się na rynku (Rabl 1995, 2). Przestępstwa brutalne i przestępstwa na tle seksualnym są , chodliwym towarem”, bo, jak wskazuje się w doktrynie, zapoznawanie się ze szczegółami takich przestępstw za pośrednictwem mediów przez widzów i czytelników spełnia funkcję sublimującą i stabilizującą (tamże, 8). Ponadto zaznacza się, iż to, co dziś nazywamy dziennikarstwem, jest w istocie „agregatem” wielu różnych aktywności medialnych, a nie, jak kiedyś, profesją kojarzącą się z wysokimi kompetencjami i poczuciem misji (Pleszczyński 2012, 67 i n.). Rewolucja cyfrowa umożliwiła zmianę paradygmatu i modyfikację modelu mediów. Dowodem tej zmiany jest istnienie tzw. dziennikarstwa obywatelskiego, przy czym to, co czasem uważane jest za zaletę takiego dziennikarstwa, czyli szybkość podawania informacji, może skutkować spadkiem jakości przekazywanych treści. Media społecznościowe nieraz udowodniły, jak niebezpieczne jest szybkie rozpowszechnianie niesprawdzonych wiadomości dotyczących procesu karnego (Rose, Fox 2014, 776). Brak regulacji doniesień internetowych w połączeniu $\mathrm{z}$ tabloidyzacją sposobu relacjonowania powoduje obawy dotyczące destrukcyjnego wpływu social mediów na publiczny dyskurs. Bez wątpienia przedstawiciele profesjonalnych mediów często są inspiracją dla tego rodzaju działań, a naruszanie intymności uczestników postępowania oraz zasady 
domniemania niewinności przez zawodowych dziennikarzy stanowią zachętę do powielania naruszeń na portalach społecznościowych czy blogach.

Warto w tym miejscu dodać, że w polskim procesie po nowelizacji Kodeksu postępowania karnego z czerwca 2016 roku możliwości sądu w kwestii ograniczania sprawozdawczości radiowo-telewizyjnej zostały uszczuplone (art. 357 $\S 5$ k.p.k.). W uzasadnieniu do noweli wprost zasugerowano chęć swoistego zrównania fizycznej obecności publiczności na sali ze sprawozdawczością radiowo-telewizyjną (Poselski projekt 2016). Znów odwołując się do Hiszpanii, wskazać można, że w hiszpańskim procesie „dwustopniowe” traktowanie wyłączania jawności zostało zachowane i ustawodawca rozdziela środki ograniczające jawność pośrednią i bezpośrednią (art. 682 Ley de enjuiciamiento criminal).

Jeśli chodzi o wizerunek pokrzywdzonych w przekazach medialnych, w polskim piśmiennictwie dostrzega się czasem, że ofiara eksponowana jest rzadko, a jeśli już, to traktowana jest instrumentalnie jako tło dla nakreślenia postaci sprawcy lub też ukazania szerszych problemów społecznych, czy wręcz jako narzędzie walki politycznej (Kulesza 1995, 1 i n.). Najczęściej prasa interesuje się ofiarą wtedy, gdy przestępstwo jest na tyle sensacyjne, że słupki sprzedaży rosną wraz z ujawnianiem kolejnych faktów. Ciekawy podział ofiar eksponowanych w prasowych doniesieniach proponuje Cezary Kulesza (tamże). W pierwszej grupie wymienia ofiary znane społeczeństwu, w tym ofiary ze świata polityki. Następnie odnosi się do trudnych tematów poruszanych przez prasę, a dalej wskazuje na ofiary przestępstw politycznych, ofiary przestępczości zorganizowanej oraz ofiary opisywane przez media jako „nieostrożne” czy „prowokujące” (tamże). Nie można zgodzić się z autorem, że wykorzystywanie ofiary jako tła dla pokazania problemów społecznych jest zjawiskiem jednoznacznie negatywnym, trudno bowiem zabraniać dziennikarzom spoglądania na opisywane sprawy w szerszej perspektywie. Kontrowersyjne jest natomiast wykorzystywanie ofiary dla przedstawienia wizerunku sprawcy, prezentowanie zaś ofiary jako tej, która „sama się prosiła" należy piętnować z całą mocą.

Bez wątpienia zainteresowanie mediów budzą uczestnicy będący osobami publicznymi. W piśmiennictwie i judykaturze panuje powszechna zgoda co do tego, iż osoby publiczne korzystają z węższego zakresu ochrony sfery życia prywatnego niż osoby prywatne (Sieńczyło-Chlabicz 2006, 242). Sąd Najwyższy stwierdził, iż, choć Konstytucja stoi na straży prawa do prywatności, nie budzi wątpliwości, że podjęcie działalności publicznej oznacza ograniczenie tego prawa dla jednostki, zwłaszcza w odniesieniu do informacji ujawnionych w toku tej działalności lub w związku z nią (post. SN z dnia 10 kwietnia 2014 r., I CSK 405/13, LEX nr 1640229; wyr. SN z dnia 28 października 2016 r., I CSK 695/15, LEX nr 2188612). Wnioskując a contrario z art. 14 ust. 6 ustawy z dnia 26 stycznia 1984 r. - Prawo prasowe (Dz.U. z 1984 r. Nr 5, poz. 24 ze zm.), informacje związane bezpośrednio z działalnością publiczną osób publicznych mogą być publikowane bez zgody takich osób. Podobnie skonstruowano przepis dotyczący 
rozpowszechniania wizerunku, który znajduje się w art. 81 ustawy z dnia 4 lutego 1994 r. o prawie autorskim i prawach pokrewnych (tekst jedn. Dz.U. z 1994 r. Nr 24, poz. 83; tekst jedn. Dz.U. z 2017 r., poz. 880). Decydującym elementem, który pozwala określić, czy bezprawnie naruszono prywatność, jest obiektywny fakt publicznego znaczenia tego, co zostało rozpowszechnione, to znaczy, czy informacja była relewantna ze względu na interes publiczny związany ze sprawą lub uzasadnione zainteresowanie odbiorców tematem. Zgodnie z art. 13 Prawa prasowego właściwy prokurator lub sąd może zezwolić, ze względu na ważny interes społeczny, na ujawnienie danych osobowych i wizerunku osób (nie tylko osób publicznych), przeciwko którym toczy się postępowanie przygotowawcze lub sądowe. $Z$ redakcji przepisu wyraźnie wynika, że zezwolenie to nie może dotyczyć świadków, pokrzywdzonych i poszkodowanych.

Należy w tym miejscu odróżnić informacje o procesie od informacji z procesu. Podawanie niektórych informacji z procesu oraz informacji o procesie może wiązać się z naruszeniem domniemania niewinności, zaś publikowanie informacji z procesu (treści zeznań, wyjaśnień) może stanowić naruszenie prawa do prywatności. W przypadku osób uwikłanych w proces pod pewnymi warunkami możliwe jest ujawnienie informacji związanych bezpośrednio z przestępstwem, natomiast inne informacje o życiu prywatnym, które zostają ujawnione en passant, powinny być chronione. Jeśli chodzi o domniemanie niewinności - nadrzędność tej zasady wymaga od mediów szczególnie starannej i neutralnej prezentacji informacji odnośnie do sprawy sub iudice (de Porres Ortiz de Urbina 2012). Nie wolno wypowiadać $\mathrm{w}$ prasie opinii co do rozstrzygnięcia w postępowaniu sądowym przed wydaniem orzeczenia w I instancji (art. 13 ust. 1 Prawa prasowego). Warto zwrócić uwagę, że polski ustawodawca traktuje kwestię antycypacji szeroko i odnosi się nie tylko do „przesądzania o winie”, ale do wszelkich „opinii co do rozstrzygnięcia", także tych korzystnych dla oskarżonego, niekorzystnych zaś dla pokrzywdzonego.

Z jednej strony wydaje się, że pokrzywdzeni będący osobami publicznymi bądź ofiary znanych sprawców mogą bronić się skuteczniej, a ich głos wybrzmiewa bardziej donośnie niż głos „zwykłych śmiertelników”, dając nikomu nieznanym pokrzywdzonym nadzieję i odwagę. $Z$ drugiej strony osoby z pierwszych stron gazet często są oceniane bardzo surowo i obserwowane z nieufnością̧

Jeśli chodzi o wąsko ujmowany zakaz antycypacji rozstrzygnięć, a więc o zasadę domniemania niewinności, warto powtórzyć za Stanisławem Waltosiem, że informacje o prowadzeniu procesu, dotyczące osoby znanej z imienia i nazwiska, są stygmatyzacją i uniewinnienie czy umorzenie postępowania nie poprawia wizerunku uprzednio oskarżonego, gdyż „nikt nie dba o skutki

${ }^{8}$ Samantha Geimer w 2010 r. wyznała, że fakt, iż sprawa Romana Polańskiego była tak nagłośniona, był koszmarem dla całej jej rodziny, tymczasem „nie powinno być tak, że działania sądu ranią bardziej niż samo przestępstwo" (zob. Filaszewska 2017b). 
gasnącej sensacji”, a „dobre wiadomości dla dotychczasowego oskarżonego są złymi wiadomościami dla prasy" (Waltoś 1997, 228). Najgorszą sankcją bywa nie kara wymierzona przez państwo, ale kara nieformalna - publiczne „zniesławienie" oskarżonego, które w sposób nienaprawialny niszczy jego dobre imię, warunki i perspektywy życiowe oraz zawodowe. Wyrok dotyczący naruszenia dóbr osobistych zapada zazwyczaj zbyt późno. Współczesna rzeczywistość doniesień kryminalnych i sądowych w mass mediach, zinternalizowana w zbiorowej wyobraźni, sprawia czasem, że na nowo można mówić o znanej przed wiekami hańbiącej funkcji prawa karnego. Pręgierz został zastąpiony przez wystawienie na widok publiczny na pierwszych stronach gazet albo na ekranach telewizorów (Van Den Dooren, 10). Przykłady takich spraw można mnożyć9. W przypadku osób publicznych nie jest nawet konieczne ujawnianie ich imienia i nazwiska, by wszyscy wiedzieli, o kogo chodzi, ponieważ wystarczy zbiór kilku innych danych, by doszło do stygmatyzacji. Taka stygmatyzacja nie jest jednak tożsama ze złamaniem prawa do prywatności. Warto podkreślić, że ujawnienie informacji o ewentualnym udziale danej osoby w popełnieniu przestępstwa nie stanowi jeszcze naruszenia prywatności, a co najwyżej naruszenie czci czy dobrego imienia.

\section{ZASADY W PRAWIE I PRAKTYCE}

Choć w procesie karnym jawność zewnętrzna pozostaje jedną z najbardziej istotnych zasad, nie ma ona charakteru bezwzględnego i w sprawach o przestępstwa na tle seksualnym de facto regułę będzie stanowiło prowadzenie procesu przy drzwiach zamkniętych. Fakt, iż sądy w sprawach o przestępstwa na tle seksualnym korzystają z możliwości wyłączenia jawności, należy oceniać pozytywnie. Wydaje się również, że narzędzia przyznane przez ustawodawcę polskim sądom dobrze spełniają w tym zakresie swoją rolę. Problemem wciąż pozostaje jednak kwestia rzetelnego przekazu medialnego oraz ochrona intymności i godności uczestników postępowania, której bez wątpienia nie zapewni samo prowadzenie sprawy przy drzwiach zamkniętych. Być może normatywne uwypuklenie pewnych kwestii dotyczących pokrzywdzonego, dokonane na wzór rozwiązań hiszpańskich czy włoskich, stanowiłoby krok

\footnotetext{
${ }^{9}$ Wystarczy przywołać stosunkowo świeży skandal, związany z producentem filmowym Harveyem Weinsteinem, który podobno miał molestować seksualnie aktorki. Na ten moment (22 lutego 2018 r.) nie tylko nie ma wyroku sądowego, ale też próżno szukać w Internecie zarzutów, jakie miały zostać postawione producentowi, czy informacji o procesie, który rzekomo miał się toczyć. Pojawiają się jedynie komentarze w sposób ewidentny łamiące zasadę domniemania niewinności, np. ,jak się okazuje, słynny producent już niedługo będzie mógł się cieszyć wolnością" czy „mamy nadzieję, że amerykański wymiar sprawiedliwości właściwie osądzi haniebne czyny producenta" (zob. Filaszewska 2017a).
} 
w dobrą stronę. Choć idealne prawo pozostanie tylko swoistą asymptotą, bez wątpienia dążenie do jego stworzenia i do możliwej precyzji przepisów zawsze będzie zadaniem prawników.

Należy przypomnieć jednak, że samo ustalenie ram prawnych nie wystarcza do rozstrzygnięcia kolizji zasad, co więcej - stworzenie zbyt sztywnych rozwiązań uniemożliwiłoby elastyczne reagowanie w konkretnych sytuacjach i mogłoby nawet pewne zasady unicestwić. Ochrona prawa do prywatności nie może paraliżować procesu, cele procesu zaś, takie jak dążenie do prawdy, nie powinny przysłaniać konieczności ochrony godności uczestników postępowania. Jak wspomniano na wstępie, możliwości faktyczne urzeczywistnienia zasady podlegają ocenie a casu ad casum w świetle zasad konieczności i odpowiedniości. Efekt ważenia zasad najczęściej będzie zależał od doświadczenia i wrażliwości ważącego i, choć takie rozwiązanie nie daje nam stuprocentowej pewności uzyskania zawsze właściwych decyzji, to jednak jest ono rozwiązaniem najlepszym z możliwych. Wszak w procesie, po obu jego stronach, stają ludzie, którzy przeżywają ból, strach i wstyd. Na szczęście także podmioty profesjonalne, takie jak sąd, to po prostu ludzie, zdolni do empatii, która wcale nie musi przekreślać obiektywizmu. Nawet najlepiej skonstruowane przepisy nie zastąpią bowiem człowieka, a zetknięcie z drugim człowiekiem nie musi być traumą, wprost przeciwnie - powinno stać się szansą uzyskania ludzkiego spojrzenia na problem.

\section{BIBLIOGRAFIA}

Aprile, Ercole, Silvestri Pietro. 2006. Il giudizio dibattimentale. Mediolan: Giuffrè.

Braciak, Joanna. 2004. Prawo do prywatności. Warszawa: Wydawnictwo Sejmowe.

De Porres Ortiz de Urbina, Eduardo. 2012. Los juicios paralelos. http://www.elderecho.com/penal/ juicios-paralelos_11_481180004.html [dostęp 10.11.2017].

Drożdż, Michał. 2012. „Etos dziennikarski bez etyki...?”. W Etyka dziennikarstwa. Edukacja. Teoria. Praktyka. Red. Elżbieta Pawlak-Hejno, Jan Pleszczyński. 31-51. Lublin: Wydawnictwo UMCS.

Frank, Priscilla. Photographer Documents What Students Wore When They Were Sexually Assaulted. https://www.huffingtonpost.com/entry/photographer-documents-what-women-wore-when-they-were-sexually-assaulted_us_5720e652e4b0f309baef5868 [dostęp 10.11.2017].

Garlicki, Leszek. 2001. „Przesłanki ograniczania konstytucyjnych praw i wolności (na tle orzecznictwa Trybunału Konstytucyjnego)". Państwo i Prawo 10: 5-24.

Goetz, Magdalena. 2002. „Wtórna wiktymizacja”. Niebieska Linia 3. http://www.niebieskalinia.pl/ pismo/-wydania/dostepne-artykuly/5093-wtorna-wiktymizacja [dostęp 10.11.2017].

Hofmański, Piotr, Elżbieta Sadzik, Kazimierz Zgryzek. 2011. Kodeks postępowania karnego. Komentarz do artykułów 297-467. T. 2. Red. Piotr Hofmański. Warszawa: Wydawnictwo C.H. Beck.

Jasiński, Wojciech. 2009. Bezstronność sądu i jej gwarancje w polskim procesie karnym. Warszawa: Wolters Kluwer Polska.

Jung, Heike. 1988. „Zasada jawności w postępowaniu karnym RFN”. PPK 4: 11-27. 
Koper, Radosław. 2010. Jawność rozprawy głównej a ochrona prawa do prywatności w procesie karnym. Warszawa: Wolters Kluwer Polska.

Kulesza, Cezary. 1997. „Ofiara przestępstwa w polskiej prasie”. W Relacje o przestępstwach $i$ procesach karnych $w$ prasie codziennej $w$ Niemczech $i$ w Polsce. Red. Dieter Dölling, Karl H. Gössel, Stanisław Waltoś. Tł. Zofia Berdychowska, Teresa Krajewska. 151-163. Kraków: Katedra Postępowania Karnego Uniwersytetu Jagiellońskiego.

Łabno, Anna. 2002. „Ograniczenie wolności i praw człowieka na podstawie art. 31 Konstytucji III RP”. W Prawa i wolności obywatelskie w Konstytucji RP. Red. Bogusław Banaszak, Artur Preisner. 293-709. Warszawa: Wydawnictwo C.H. Beck.

Maroń, Grzegorz. 2009. „Formuła ważenia zasad prawa jako mechanizm usuwania ich kolizji na przykładzie koncepcji Roberta Alexego". Zeszyty Naukowe Uniwersytetu Rzeszowskiego. Seria Prawnicza 7 (53): 86-106.

Parzyński, Jerzy. 1964. „O metodykę współpracy z wymiarem sprawiedliwości”. Zeszyty Prasoznawcze 1-2: 54-67.

Pleszczyński, Jan. 2012. „Jaka etyka dziennikarska jest potrzebna i możliwa?”. W Etyka dziennikarstwa. Edukacja. Teoria. Praktyka. Red. Elżbieta Pawlak-Hejno, Jan Pleszczyński. 67-78. Lublin: Wydawnictwo UMCS.

Postema, Gerald J. 2013. The Soul of Justice: Bentham on Publicity, Law, and the Rule of Law. https://papers.ssrn.com/sol3/papers.cfm?abstract_id=2294730 [dostęp 10.11.2017].

Powszechna Deklaracja Praw Człowieka.http://www.unesco.pl/fileadmin/user_upload/pdf/Powszechna_Deklaracja_Praw_Czlowieka.pdf [dostęp 10.11.2017].

Rabl, Herbert W. 1995. „Doniesienia kryminalne z dziennikarskiego punktu widzenia”. W Sprawo$z$ dawczość prasowa z procesów karnych i relacje o przestępstwach $w$ Niemczech $i$ w Polsce [Materiały pokonferencyjne z konferencji, która odbyła się dnia 4 grudnia 1995 roku w Krakowie - maszynopis]. 1-35.

Rose, Michelle, Richard L. Fox. 2014. „Public Engagement with the Criminal Justice System in the Age of Social Media”. Oñati Socio-legal Series 4 (4) - Law in the Age of Media Logic: $771-798$

Sieńczyło-Chlabicz, Joanna. 2006. Naruszenie prywatności osób publicznych przez prasę. Analiza cywilnoprawna. Kraków: Kantor Wydawniczy Zakamycze, Oddział Polskich Wydawnictw Profesjonalnych.

Van Den Dooren, Sebastián. La publicidad en el proceso penal. http:/www.alfonsozambrano.com/ doctrina penal/publicidad proceso penal.doc [dostęp 10.11.2017].

Waltoś, Stanisław. 1997. „Zasada domniemania niewinności a środki masowego przekazu”. Studia Iuridica 33: 223-232.

Zgryzek, Kazimierz. 2014. System prawa karnego procesowego. T. 3: Zasady procesu karnego. Cz. 2. Red. Paweł Wiliński. 768-832. Katowice: Wolters Kluwer Polska.

\section{Źródła}

Filaszewska, Olga. 2017a. „Harvey Weinstein wkrótce zostanie aresztowany!”. Viva.pl. http://viva. pl/ludzie/newsy/weinstein-aresztowany-kolejne-zarzuty-gwalty-molestowania-zlamane-zycie-producenta-111884-r1/ [dostęp 20.02.2018].

Filaszewska, Olga. 2017b. „«Sąd zadał mi więcej bólu niż Polański». Samantha Geimer staje w obronie reżysera". Viva.pl. http://viva.pl/ludzie/newsy/ofiara-polanskiego-broni-rezysera-110221-r1/ [dostęp 20.02.2018].

Michaluk, Paweł. 2008. „Prośba o gwałt”. Kampanie społeczne.pl. http://kampaniespoleczne.pl/ prosba-o-gwalt/ [dostęp 10.11.2017]. 


\section{Orzecznictwo}

Postanowienie SA w Warszawie z dnia 19 grudnia 2013 r., II AKz 856/13, LEX nr 1403834.

Postanowienie SN z dnia 10 kwietnia 2014 r., I CSK 405/13, LEX nr 1640229.

Sentencia del Tribunal Constitucional 151/1997 z dnia 29 sierpnia 1997 r., BOE nr 260, z dnia 30 października $1997 \mathrm{r}$.

Sentencia del Tribunal Supremo 661/2016 z dnia 10 listopada 2016 r.

Wyrok SA w Gdańsku z dnia 8 kwietnia 2015 r., II AKa 79/15, LEX nr 1927698.

Wyrok SA w Katowicach z dnia 20 września 2012 r., V ACa 378/12, LEX nr 1220491.

Wyrok SA w Krakowie z dnia 11 kwietnia 2001 r., I ACa 244/01, TPP 2002/3/125.

Wyrok SA w Warszawie z dnia 12 listopada 2013 r., I ACa 906/13, LEX nr 1409385.

Wyrok SN z dnia 28 października 2016 r., I CSK 695/15, LEX nr 2188612.

Wyrok TK z dnia 9 czerwca 1998 r., sygn. K 28/97, Z.U. 1998/4/50.

Wyrok TK z dnia 8 grudnia 1998 r., sygn. K 41/97, Dz.U. z 1998 r. Nr 158, poz. 1043.

Wyrok TK z dnia 16 marca 1999 r. SK 19/98, Dz.U. z 1999 r. Nr 022, poz. 211.

Wyrok TK z dnia 2 października 2006 r. SK 34/06, Dz.U. z 2006 r. Nr 186, poz. 1379.

\section{Akta prawne i materiały legislacyjne}

Codice di Procedura Penale (testo coordinato ed aggiornato del D.P.R. $z$ dnia 22 września 1988 r., n. 447).

Constitución Española z dnia 29 grudnia 1978 r. (BOE-A-1978-31229).

Dyrektywa Parlamentu Europejskiego i Rady 2012/29/UE z dnia 25 października 2012 r. ustanawiająca normy minimalne w zakresie praw, wsparcia i ochrony ofiar przestępstw oraz zastępująca decyzję ramową Rady 2001/220/WSiSW.

Konstytucja Rzeczypospolitej Polskiej z dnia 2 kwietnia 1997 r. (Dz.U. z 1997 r. Nr 78, poz. 483 z dnia 16 lipca 1997 r.).

Konwencja o Ochronie Praw Człowieka i Podstawowych Wolności z dnia 4 listopada 1950 r. ze zm. (Dz.U. z 1993 r. Nr 61, poz. 284).

Ley de Ayuda y Asistencia a las Víctimas de Delitos Violentos y contra la Libertad Sexual (ustawa z dnia 11 grudnia 1995 r., 35/1995, BOE nr 296 z dnia 12 grudnia 1995 r., BOE-A-1995-26714, ze zm.).

Ley de enjuiciameinto criminal z dnia 14 września 1882 r. (BOE nr 260, z dnia 17 września 1882 r., BOE-A-1882-6036, ze zm.).

Ley de Medidas de Protección Integral contra la Violencia de Género z dnia 28 grudnia 2004 r., 1/2004 (BOE nr 313, z dnia 29 grudnia 2004 r., BOE-A-2004-21760, ze zm.).

Międzynarodowy Pakt Praw Obywatelskich i Politycznych z dnia 19 grudnia 1966 r. (Dz.U. z 1977 r. Nr 38, poz. 167).

Poselski projekt ustawy o zmianie ustawy - Kodeks postępowania karnego oraz niektórych innych ustaw. 25.04.2016. Druk nr 451. http://www.sejm.gov.pl/Sejm8.nsf/druk.xsp?nr=451 [dostęp 10.11.2017].

Ustawa z dnia 26 stycznia 1984 r. - Prawo prasowe (Dz.U. z 1984 r. Nr 5, poz. 24. ze zm.).

Ustawa z dnia 4 lutego 1994 r. o prawie autorskim i prawach pokrewnych (Dz.U. z 1994 r. Nr 24, poz. 83; tekst jedn. Dz.U. z 2017 r., poz. 880).

Ustawa z dnia 6 czerwca 1997 r. - Kodeks postępowania karnego (tekst jedn. Dz.U. z 2016 r., poz. 1749 ze zm.). 
Paulina Konca

\title{
THE PRINCIPLE OF PUBLICITY AND THE RIGHT TO PRIVACY IN CASES WITH SEXUAL OFFENCE BEING THE ISSUE OF THE PENAL PROCEEDINGS. COMPARATIVE APPROACH
}

\begin{abstract}
The article concerns a conflict between the right to privacy and the principle of external publicity, including some other principles of criminal procedure in terms of cases with a sexual offence being the issue of the proceedings. The author presents the Polish regulations against the background of the Spanish ones and refers to social campaigns and solutions that function in other European countries in order to demonstrate both the importance of the victim's dignity and right to privacy protection in view of preventing the secondary victimization. She also tries to show the mechanisms ensuring such protection. Moreover, the author analyses the issue of the defendant's right to privacy protection. Because the principle of external openness is closely related to the access of the media to a trial, the article also focused on the radio and television reporting in the context of new media development with a particular emphasis on matters involving public figures.
\end{abstract}

Keywords: principles, criminal procedure, Spanish law, secondary victimization, right to privacy, principle of external publicity. 